\title{
High genetic similarity of Streptococcus agalactiae and Streptococcus difficilis: S. difficilis Eldar et al. 1995 is a later synonym of $S$. agalactiae Lehmann and Neumann 1896 (Approved Lists 1980)
}

\author{
Yoshiaki Kawamura, ${ }^{1}$ Yoko Itoh, ${ }^{1}$ Noriko Mishima, ${ }^{1}$ Kiyufumi Ohkusu, ${ }^{1}$ \\ Hiroaki Kasai $^{2}$ and Takayuki Ezaki ${ }^{1}$ \\ ${ }^{1}$ Department of Microbiology, Regeneration and Advanced Medical Science, Gifu University
Graduate School of Medicine, 1-1 Yanagido, Gifu 501-1194, Japan \\ ${ }^{2}$ Marine Biotechnology Institute, 3-75-1 Heita, Kamaishi, Iwate, Japan
}

\begin{abstract}
The genetic relationship between Streptococcus agalactiae and Streptococcus difficilis was studied. S. difficilis was originally described as serologically non-typable but was later reported to be a group B, type lb streptococcus. Upon comparative analysis of five gene sequences, it was found that $S$. agalactiae and $S$. difficilis are closely related. Sequence similarity values between these two species were $100 \cdot 0 \%$ for $16 \mathrm{~S}$ rRNA, $99.6 \%$ for $\operatorname{gyr} B, 98 \cdot 6 \%$ for $\operatorname{sod} A, 99.5 \%$ for gyrA and $99.8 \%$ for parC genes. These data strongly suggest that $S$. agalactiae and $S$. difficilis are synonyms. The biochemical characteristics of $S$. difficilis, which differ slightly from those of typical S. agalactiae, are similar to those of other group B, type lb streptococci isolated from fish and frogs. Whole genome DNA-DNA hybridization values between the type strains of both species were greater than $78.6 \%$. On the basis of these data, it is proposed that $S$. difficilis is a later synonym of $S$. agalactiae.
\end{abstract}

\section{INTRODUCTION}

Group B streptococci are synonymous with Streptococcus agalactiae. Strains of this species have been recovered predominantly from bovine and human sources but have been isolated occasionally from several homeothermic animals (cats, dogs, hamsters) and also from some poikilothermic animals, including frogs and fish (Dow et al., 1987; Kornblatt et al., 1983; Kummeneje et al., 1975). Most strains of the species show $\beta$-haemolysis on blood agar, although a number of non-haemolytic, type Ib variants have been isolated from humans, cows and fish (Amborski et al., 1983; Wilkinson et al., 1973). Wilkinson et al. (1973) and Elliott et al. (1990) characterized individual, non-haemolytic, serotype Ib strains of group B streptococci by biochemical analysis and whole-cell protein analysis, respectively. Wilkinson et al. (1973) reported several biochemical

Published online ahead of print on 12 November 2004 as DOI 10.1099/ijs.0.63403-0.

The GenBank/EMBL/DDBJ accession numbers for the 16S rRNA, gyrB, sodA, gyrA and parC gene sequences discussed in this study can be found in Fig. 1.

Tables giving details of the biochemical characteristics of Streptococcus difficile and Streptococcus agalactiae, and the sequence similarity data for various Streptococcus species are available as supplementary material in IJSEM Online. differences between fish isolates and those from other sources (humans and cows), whereas Elliott et al. (1990) showed no differences in whole-cell protein patterns in strains isolated from fish, mice and humans.

Eldar et al. (1994) proposed two novel streptococcal species, Streptococcus shiloi and Streptococcus difficilis [Streptococcus difficile (sic), the species epithet was corrected by Euzéby (1998)] isolated from meningoencephalitis in fish. However, the next year these authors reported that $S$. shiloi was a later synonym of Streptococcus iniae, isolated from a dolphin (Eldar et al., 1995). Vandamme et al. (1997) reported that $S$. difficilis is a group B, serotype Ib streptococcus with whole-cell protein characteristics indistinguishable from those of $S$. agalactiae. Furthermore, Berridge et al. (2001) reported genetic similarity between S. difficilis and S. agalactiae by analysis of the $16 \mathrm{~S}-23 \mathrm{~S}$ intergenic rRNA gene sequence.

In a study of the fluoroquinolone resistance of S. agalactiae strains, we found that the gene sequences of quinolone resistance determining regions (QRDRs) of both gyrA and parC between $S$. agalactiae and $S$. difficilis were almost identical (Kawamura et al., 2003). In the initial phase of the study, we hypothesized that this was due to horizontal gene transfer. However, we first needed to clarify the taxonomic relationship between these two species. 
The aim of the present study was to clarify the relationship between S. agalactiae and S. difficilis. For this, we collected sequence data on the genetic similarity of three housekeeping genes (16S rRNA, sodA and gyrB) and two quinolone resistance-related genes (gyrA and parC) (Kasai et al., 2000; Kawamura et al., 1999, 2003). We also confirmed the whole genome DNA similarity of the type strains of S. agalactiae and S. difficilis, because Eldar et al. (1994) did not use the type strain of $S$. agalactiae in their study. On the basis of our results, we propose that $S$. difficilis is a later synonym of $S$. agalactiae.

\section{METHODS}

Bacterial strains. We used the type strain and a reference strain of S. difficilis [GTC $730^{\mathrm{T}}\left(=\right.$ ATCC $\left.51487^{\mathrm{T}}\right)$ and GTC $2049(=\mathrm{CIP}$ 103853)]. We also used the type strains of $S$. agalactiae (GTC $1234^{\mathrm{T}}=$ NCTC $8181^{\mathrm{T}}$ ), Streptococcus pyogenes $\left(\mathrm{GTC} 262^{\mathrm{T}}=\right.$ ATCC $\left.12344^{\mathrm{T}}\right)$, Streptococcus canis (GTC $423^{\mathrm{T}}=$ ATCC $\left.43496^{\mathrm{T}}\right)$, Streptococcus dysgalactiae subsp. dysgalactiae (GTC $431^{\mathrm{T}}=\mathrm{NCFB} 2023^{\mathrm{T}}$ ), Streptococcus dysgalactiae subsp. equisimilis $\left(\right.$ GTC $842^{\mathrm{T}}=\mathrm{NCFB}$ $\left.1356^{\mathrm{T}}\right)$, Streptococcus equi subsp. equi (GTC $269^{\mathrm{T}}=\mathrm{NCTC} 9682^{\mathrm{T}}$ ), Streptococcus equi subsp. zooepidemicus (GTC $542^{\mathrm{T}}=$ ATCC $43079^{\mathrm{T}}$ ), Streptococcus iniae (GTC $244^{\mathrm{T}}=$ ATCC $29178^{\mathrm{T}}$ ), Streptococcus porcinus $\left(\right.$ GTC $543^{\mathrm{T}}=$ ATCC $\left.43138^{\mathrm{T}}\right)$, Streptococcus uberis $\left(\mathrm{GTC} 271^{\mathrm{T}}=\right.$ NCTC $3858^{\mathrm{T}}$ ) and Streptococcus parauberis $\left(\right.$ GTC $539^{\mathrm{T}}=\mathrm{NCDO}$ $\left.2020^{\mathrm{T}}\right)$.

All strains were grown on Columbia blood ( $5 \%$ defibrinated sheep blood) agar plates at 30 or $37^{\circ} \mathrm{C}$ under aerobic conditions unless indicated otherwise.

Biochemical profiles. Biochemical traits were determined by using the Rapid ID32 Strep (bioMérieux) and STREPTOGRAM (Wako Pure Chemical) systems according to manufacturers' recommendations, i.e. suggested incubation of test plates at $37^{\circ} \mathrm{C}$ under aerobic conditions (Kawamura et al., 1995). We also collected data on biological activity at $30^{\circ} \mathrm{C}$ under aerobic conditions, at $37^{\circ} \mathrm{C}$ in $5 \% \mathrm{CO}_{2}$ and at $37^{\circ} \mathrm{C}$ under anaerobic conditions.

Gene sequences and phylogenetic analysis. Sequences from $16 \mathrm{~S}$ rRNA, superoxide dismutase ( $\operatorname{sod} A)$, DNA gyrase subunit B $(g y r B)$, DNA gyrase subunit A (gyrA) and DNA topoisomerase subunit $C$ ( $\operatorname{par} C$ ) genes were used to investigate the genetic relationship between $S$. difficilis and $S$. agalactiae. PCR primers used for amplification of the $16 \mathrm{~S}$ rRNA, sodA, gyrA and parC genes were as described previously (Kawamura et al., 1999, 2003). The primers for amplification of gyrB were GY105G-f (5'-GAA GTC ATC ATG ACC GTT CTG CAY GSN GGN GGN AAR TTY GG-3') and GY404-r (5'-TGT AAA ACG ACG GCC AGT TCN GCN NAR YTT NCC NGG-3'). After confirming single amplification products for each gene on $1 \%$ agarose gels, sequences were determined by using an automated sequencer (model 3100; Applied Biosystems) using a dye-terminator reaction kit (Applied Biosystems).

The CLUSTAL $\mathrm{W}$ software originally described by Thompson et al. (1994) was used to align sequences, and phylogenetic distances were calculated by using the neighbour-joining method. Phylogenetic trees were drawn using TreeView software (Page, 1996).

Microplate DNA-DNA hybridization. DNA from each strain was carefully prepared by the standard procedure of Marmur (1961). We also used the silica-guanidinium thiocyanate DNA purification method described previously (Boom et al., 1990).

Quantitative microplate DNA-DNA hybridization was carried out as described previously (Ezaki et al., 1989). Hybridization experiments were carried out at $31{ }^{\circ} \mathrm{C}$ (optimal condition) and $41{ }^{\circ} \mathrm{C}$ (stringent condition) using $2 \times$ SSC and $50 \%$ formamide. The optimal temperature was $55^{\circ} \mathrm{C}$ below the thermal denaturation temperature, because formamide lowered the hybridization temperature (Meinkoth \& Wahl, 1984).

\section{RESULTS AND DISCUSSION}

\section{Physiological and biochemical characteristics}

The type strain and reference strain of $S$. difficilis grew well at $30{ }^{\circ} \mathrm{C}$ under aerobic, $5 \% \mathrm{CO}_{2}$ and anaerobic conditions. The first generation of these strains from stock cultures (stored at $-80{ }^{\circ} \mathrm{C}$ in $10 \%$ skimmed milk) did not grow well at $37^{\circ} \mathrm{C}$ in any atmosphere (air, $5 \% \mathrm{CO}_{2}$ or anaerobic). However, from the second generation, both strains grew under each of those conditions.

With a Slidex Strepto-kit (bioMérieux), we confirmed that these two strains possessed the Lancefield group B antigen. They were non-haemolytic when cultured on sheep blood agar (under both aerobic and anaerobic conditions).

Biochemical traits determined with the two commercial kits are summarized in Supplementary Table A in IJSEM Online. The biochemical profiles did not differ, even under different incubation conditions $\left(37^{\circ} \mathrm{C}\right.$ aerobic, $37^{\circ} \mathrm{C} 5 \%$ $\mathrm{CO}_{2}, 37^{\circ} \mathrm{C}$ anaerobic and $30^{\circ} \mathrm{C}$ aerobic). Almost all traits were similar to those described by Eldar et al. (1994), with the exception of the hydrolysis activity of hippurate, for which they reported no activity, but we observed a clear positive reaction. However, acid production from ribose, which has been reported to be a positive characteristic, was negative in this study. Some of the biochemical characteristics of the S. difficilis strains did not fit the typical pattern of S. agalactiae (see Supplementary Table A).

The biochemical patterns of the S. difficilis strains were similar to those of other group B, type Ib streptococci isolated from poikilothermic host animals, such as frogs and fish. Elliott et al. (1990) reported that group B, type Ib streptococci isolated from frogs were negative for reactivity in fermentation tests of lactose, salicin and trehalose, whereas isolates from cows, mice and humans showed positive reactivity in these tests. With respect to group B streptococci isolated from fish, Elliott et al. (1990) reported positive reactivity in these three fermentation tests. However, Wilkinson et al. (1973) reported no reactivity in these. Wanger \& Dunny (1985) described the association of transposon infection and mutation in some biochemical reactions. They showed that insertion of the Tn916 transposon in S. agalactiae strains causes slow lactose fermentation and also defective fermentation of trehalose. Other researchers explained that the biochemical divergence of frog or fish isolates from cow or human isolates may lead to phenotypic adaptations in the host (Elliott et al., 1990). We did not investigate whether the strains of S. difficilis carried transposons. These elements may be a reason for the phenotypic diversity. 

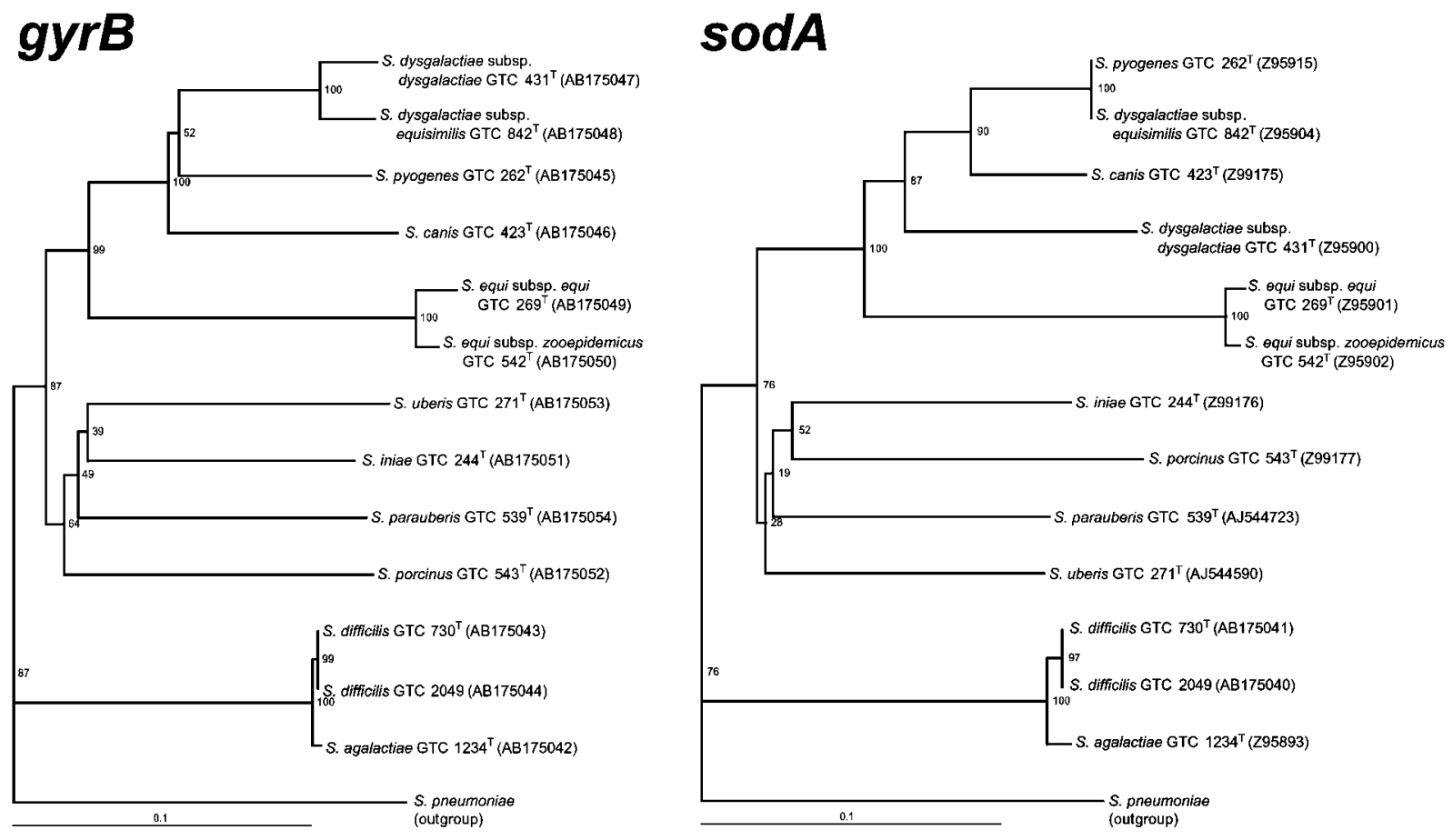

\section{gyrA}

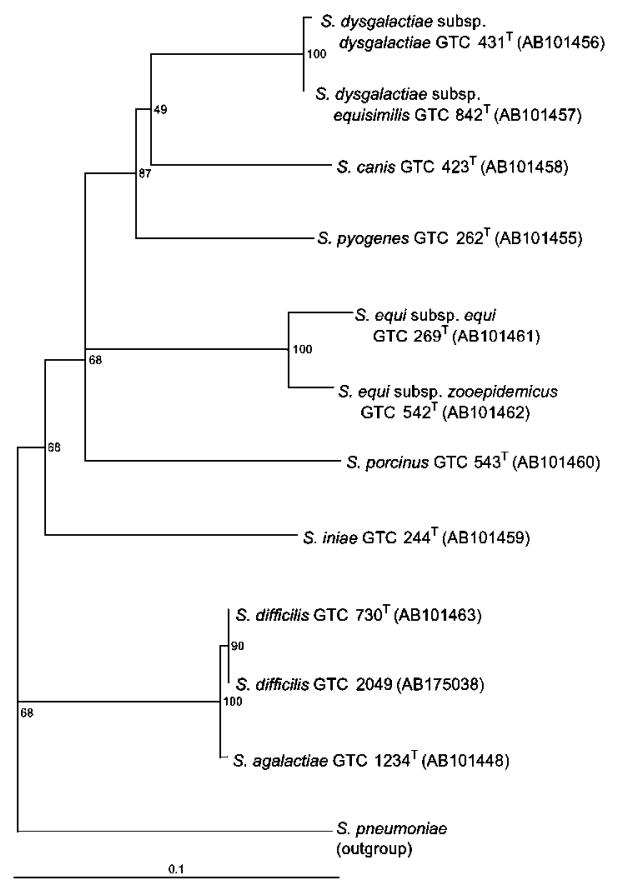

\section{parc}

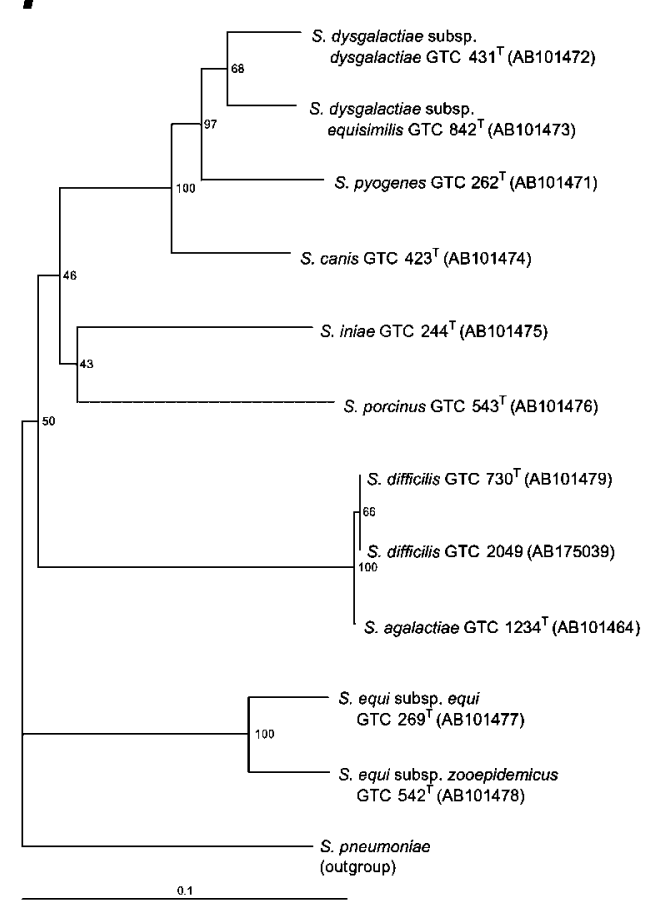

Fig. 1. Comparative phylogenetic trees constructed from gyrB, sodA, gyrA and parC gene sequences. Distances were calculated by using the neighbour-joining method. The scales of the phylogenetic trees are identical. Bar, $10 \%$ sequence divergence. S. agalactiae and $S$. difficilis were neighbours, with very little sequence divergence, in all of the phylogenetic trees. 
Table 1. DNA-DNA hybridization values

Each value represents the mean $\pm \mathrm{SD}$ of three experiments.

\begin{tabular}{|c|c|c|c|c|c|c|}
\hline \multirow[t]{3}{*}{ Strains } & \multicolumn{6}{|c|}{ DNA hybridization (\%) with biotin-labelled DNA from: } \\
\hline & \multicolumn{2}{|c|}{ S. agalactiae GTC $1234^{\mathrm{T}}$} & \multicolumn{2}{|c|}{ S. difficilis GTC $730^{\mathrm{T}}$} & \multicolumn{2}{|c|}{ S. difficilis GTC 2049} \\
\hline & Optimal & Stringent & Optimal & Stringent & Optimal & Stringent \\
\hline S. agalactiae GTC $1234^{\mathrm{T}}$ & $100 \cdot 0$ & $100 \cdot 0$ & $78 \cdot 6 \pm 1 \cdot 6$ & $75 \cdot 7 \pm 0 \cdot 6$ & $77 \cdot 8 \pm 0 \cdot 7$ & $75 \cdot 4 \pm 0 \cdot 1$ \\
\hline S. difficilis GTC $730^{\mathrm{T}}$ & $84 \cdot 2 \pm 1 \cdot 5$ & $79 \cdot 7 \pm 1 \cdot 0$ & $100 \cdot 0$ & $100 \cdot 0$ & $100 \cdot 0 \pm 1 \cdot 3$ & $93 \cdot 9 \pm 0 \cdot 4$ \\
\hline S. difficilis GTC 2049 & $85 \cdot 3 \pm 1 \cdot 2$ & $80 \cdot 3 \pm 1 \cdot 5$ & $100 \cdot 0 \pm 1 \cdot 9$ & $91 \cdot 8 \pm 0 \cdot 5$ & $100 \cdot 0$ & $100 \cdot 0$ \\
\hline Salmon DNA & $0 \cdot 0$ & $0 \cdot 0$ & $0 \cdot 0$ & $0 \cdot 0$ & $0 \cdot 0$ & $0 \cdot 0$ \\
\hline
\end{tabular}

\section{Sequence similarity}

Phylogenetic analysis of the 16S rRNA gene sequence clearly revealed that $S$. difficilis is a member of the pyogenic group of the genus Streptococcus (data not shown). The closest relative was $S$. agalactiae, with which it shared identical sequence.

It is well known that comparative analysis of the $16 \mathrm{~S}$ rRNA gene sequence is not suitable for the investigation of genetically closely related strains, because the rate of evolution of the $16 \mathrm{~S}$ rRNA gene is relatively slow (Kawamura et al., 1999). Therefore, we used four other genes $(g y r B$, sodA, gyrA and parC) to investigate the genetic relationship between $S$. difficilis and other members of the pyogenic group, particularly $S$. agalactiae. Sequence similarity values for selected members of the pyogenic group of the genus Streptococcus are available as Supplementary Table B in IJSEM Online, and the phylogenetic trees are shown in Fig. 1. S. difficilis and S. agalactiae constituted a cluster that was separate from other Streptococcus species in all four gene-based phylogenetic trees (Fig. 1). Two different strains of $S$. difficilis (the type strain and a reference strain) shared identical sequences in all five of the genes studied. S. agalactiae and S. difficilis showed very high sequence similarity in the five gene sequences: $100 \cdot 0 \%$ for 16S rRNA (1320 bp compared), 99.6\% for $\operatorname{gyrB}$ (900 bp), $98.6 \%$ for $\operatorname{sodA}(366 \mathrm{bp}), 99.5 \%$ for $\operatorname{gyrA}(420 \mathrm{bp})$ and $99 \cdot 8 \%$ for $\operatorname{parC}(528 \mathrm{bp})$.

Two pairs of subspecies ( $S$. dysgalactiae subsp. dysgalactiae and S. dysgalactiae subsp. equisimilis; S. equi subsp. equi and S. equi subsp. zooepidemicus) constituted single clusters in all four trees, with the exception of $S$. dysgalactiae subspecies in the sodA tree (Fig. 1). However, the genetic distances of the $S$. difficilis/S. agalactiae clusters were less than those of the two subspecies pairs. The sequence similarity values also showed the relatedness of these two species (see Supplementary Table B). Both sets of data clearly show that the relatedness of $S$. difficilis and $S$. agalactiae is greater than that of subspecies level. Along with the report of Berridge et al. (2001) on the genetic similarity of $S$. difficilis and S. agalactiae by analysis of 16S23S intergenic rRNA gene sequences, our data strongly suggest that these two species are genetically very similar.

\section{Whole genome DNA hybridization analysis}

The DNA-DNA hybridization values obtained under optimal $\left(31^{\circ} \mathrm{C}\right)$ and stringent $\left(41{ }^{\circ} \mathrm{C}\right)$ conditions are shown in Table 1 . The two strains of $S$. difficilis were almost identical, with a hybridization value greater than $91 \cdot 8 \%$ obtained even under stringent conditions.

Minimum hybridization values of $77 \cdot 8$ and $75 \cdot 4 \%$ were obtained between the type and reference strains of $S$. agalactiae and $S$. difficilis, under optimal and stringent conditions, respectively. These values proved that the two species are synonyms.

Eldar et al. (1994) reported a DNA-DNA hybridization value of only $30.8 \%$ between $S$. difficilis and S. agalactiae, but they did not use the type strain of $S$. agalactiae. However, we observed values greater than $77 \cdot 8 \%$ between the type strain of $S$. agalactiae $\left(\right.$ GTC $1234^{\mathrm{T}}=$ NCTC $\left.8181^{\mathrm{T}}\right)$ and two different strains of $S$. difficilis $\left(\right.$ GTC $730^{\mathrm{T}}=$ ATCC $51487^{\mathrm{T}}$ and GTC $2049=$ CIP 103853). Even though the strains were different, these data are quite different. We cannot explain this discrepancy with certainty. One possible reason is the difference in the DNA-DNA hybridization methods used; Eldar et al. (1994) used the hydroxyapatite method, whereas we used microplate hybridization method. Another possibility is that a contaminating component of the DNA preparation interfered with the re-association of the DNA heteroduplex. The strains of $S$. difficilis (we used two reference strains) were very mucoidal, and some capsule components (polysaccharides or glycopeptides) were difficult to remove during DNA extraction and easily contaminated the samples. In our experience, DNA extracted from the strains of $S$. difficilis by the Marmur method was very sticky, probably due to such contamination. With these samples, the DNA-DNA hybridization data were inconsistent (data not shown), and we could not obtain stable and reliable data. Consequently, we used the silicaguanidinium thiocyanate DNA purification method, which resulted in relatively pure DNA. Thus, we collected stable and reliable data with this purification method.

Wanger \& Dunny (1985) reported that human and bovine strains of $S$. agalactiae of various serotypes (serotypes Ia, Ib, Ic, II and III) show significantly high DNA-DNA 
hybridization values, indicating no correlation between DNA-DNA hybridization values and serotypes within group B streptococci. Vandamme et al. (1997) also reported that strains isolated from various hosts, such as humans, cows, dogs, cats and pigs, belonged to a single cluster based on the numerical analysis of whole-cell protein profiles. Furthermore, Elliott et al. (1990) showed that strains isolated from humans, mice and fish shared identical wholecell protein profiles. These reports strongly suggest that the majority of strains of group B streptococci isolated from different hosts belong to a single cluster.

Considering the data presented here and data from other researchers, we conclude that $S$. difficilis isolated from meningoencephalitis in fish is indistinguishable from $S$. agalactiae, particularly the non-haemolytic, type $\mathrm{Ib}$ variant strains, physiologically, biochemically and genetically. Therefore, we propose that $S$. difficilis is a later synonym of S. agalactiae.

\section{REFERENCES}

Amborski, R. L., Snider, T. G., 3rd, Thune, R. L. \& Culley, D. D., Jr (1983). A non-hemolytic, group B Streptococcus infection of cultured bullfrogs, Rana catesbeiana, in Brazil. J Wildl Dis 19, 180-184.

Berridge, B. R., Bercovier, H. \& Frelier, P. F. (2001). Streptococcus agalactiae and Streptococcus difficile 16S-23S intergenic rDNA: genetic homogeneity and species-specific PCR. Vet Microbiol 78, 165-173.

Boom, R., Sol, C. J., Salimans, M. M., Jansen, C. L., Wertheim-van Dillen, P. M. \& van der Noordaa, J. (1990). Rapid and simple method for purification of nucleic acids. J Clin Microbiol 28, 495-503.

Dow, S. W., Jones, R. L., Thomas, T. N., Linn, K. A. \& Hamilton, H. B. (1987). Group B streptococcal infection in two cats. J Am Vet Med Assoc 190, 71-72.

Eldar, A., Bejerano, Y. \& Bercovier, H. (1994). Streptococcus shiloi and Streptococcus difficile: two new streptococcal species causing a meningoencephalitis in fish. Curr Microbiol 28, 139-143.

Eldar, A., Frelier, P. F., Assenta, L., Varner, P. W., Lawhon, S. \& Bercovier, H. (1995). Streptococcus shiloi, the name for an agent causing septicemic infection in fish, is a junior synonym of Streptococcus iniae. Int J Syst Bacteriol 45, 840-842.

Elliott, J. A., Facklam, R. R. \& Richter, C. B. (1990). Whole-cell protein patterns of nonhemolytic group $\mathrm{B}$, type $\mathrm{Ib}$, streptococci isolated from humans, mice, cattle, frogs, and fish. J Clin Microbiol 28, 628-630.
Euzéby, J. P. (1998). Taxonomic note: necessary correction of specific and subspecific epithets according to Rules $12 \mathrm{c}$ and $13 \mathrm{~b}$ of the International Code of Nomenclature of Bacteria (1990 Revision). Int J Syst Bacteriol 48, 1073-1075.

Ezaki, T., Hashimoto, Y. \& Yabuuchi, E. (1989). Fluorometric deoxyribonucleic acid-deoxyribonucleic acid hybridization in microdilution wells as an alternative to membrane filter hybridization in which radioisotopes are used to determine genetic relatedness among bacterial strains. Int J Syst Bacteriol 39, 224-229.

Kasai, H., Ezaki, T. \& Harayama, S. (2000). Differentiation of phylogenetically related slowly growing mycobacteria by their gyrB sequences. J Clin Microbiol 38, 301-308.

Kawamura, Y., Sultana, F., Hou, X. G. \& Ezaki, T. (1995). Evaluation of a new streptococcal identification kit "STREPTOGRAM". J Jpn Soc Clin Microbiol 5, 4-12 (in Japanese).

Kawamura, Y., Whiley, R. A., Shu, S. E., Ezaki, T. \& Hardie, J. M. (1999). Genetic approaches to the identification of the mitis group within the genus Streptococcus. Microbiology 145, 2605-2613.

Kawamura, Y., Fujiwara, H., Mishima, N., Tanaka, Y., Tanimoto, A., Ikawa, S., Itoh, Y. \& Ezaki, T. (2003). First Streptococcus agalactiae isolates highly resistant to quinolones, with point mutations in $g y r A$ and parC. Antimicrob Agents Chemother 47, 3605-3609.

Kornblatt, A. N., Adams, R. L., Barthold, S. W. \& Cameron, G. A. (1983). Canine neonatal deaths associated with group B streptococcal septicemia. J Am Vet Med Assoc 183, 700-701.

Kummeneje, K., Nesbakken, T. \& Mikkelsen, T. (1975). Streptococcus agalactiae infection in a hamster. Acta Vet Scand 16, 554-556.

Marmur, J. (1961). A procedure for the isolation of deoxyribonucleic acid from micro-organisms. Mol Biol 3, 208-218.

Meinkoth, J. \& Wahl, G. (1984). Hybridization of nucleic acids immobilized on solid supports. Anal Biochem 138, 267-284.

Page, R. D. M. (1996). TreeView: an application to display phylogenetic trees on personal computers. Comput Appl Biosci 12, 357-358.

Thompson, J. D., Higgins, D. G. \& Gibson, T. J. (1994). CLUSTAL W: improving the sensitivity of progressive multiple sequence alignment through sequence weighting, position-specific gap penalties and weight matrix choice. Nucleic Acids Res 22, 4673-4680.

Vandamme, P., Devriese, L. A., Pot, B., Kersters, K. \& Melin, P. (1997). Streptococcus difficile is a nonhemolytic group B, type Ib Streptococcus. Int J Syst Bacteriol 47, 81-85; erratum 48, 331.

Wanger, A. R. \& Dunny, G. M. (1985). Development of a system for genetic and molecular analysis of Streptococcus agalactiae. Res Vet Sci 38, 202-208.

Wilkinson, H. W., Thacker, L. G. \& Facklam, R. R. (1973). Nonhemolytic group B streptococci of human, bovine, and ichthyic origin. Infect Immun 7, 496-498. 